\title{
Multimodal Treatment of Primary Advanced Ovarian Cancer
}

\author{
MICHAEL FRIEDRICH ${ }^{1}$, DOMINIQUE FRIEDRICH ${ }^{1}$, CLAYTON KRAFT $^{2}$ and CHRISTOPH ROGMANS 3 \\ ${ }^{1}$ Klinik für Frauenheilkunde und Geburtshilfe, Helios Klinikum, Krefeld, Germany; \\ ${ }^{2}$ Klinik für Orthopädie und Unfallchirurgie, Helios Klinikum, Krefeld, Germany; \\ ${ }^{3}$ Klinik für Frauenheilkunde und Geburtshilfe, \\ Universitätsklinikum Schleswig-Holstein, Campus Kiel, Kiel, Germany
}

\begin{abstract}
Epithelial ovarian cancer is the second most common malignancy of the female genital tract, with approximately 7,400 new cases annually in Germany. With 5,500 deaths per year, ovarian cancer is the leading gynecologic cause of death. Epithelial ovarian cancer is characterized by morphologic heterogeneity with 4 molecular biological subtypes (immunoreactive-like, differentiated-like, proliferative-like, mesenchymal-like) with different prognosis. Significantly improved survival is achieved by optimal debulking with no residual disease (R0). Systematic lymphonodectomy of clinical negative lymph nodes has no effect on overall survival in advanced ovarian cancer. Interval debulking in advanced ovarian cancer after three cycles of neoadjuvant chemotherapy with carboplatin/paclitaxel is controversial. Standard chemotherapy for advanced ovarian cancer consists of six cycles of carboplatin AUC5 and paclitaxel $175 \mathrm{mg} / \mathrm{m}^{2}$, in a three-week cycle. Intraperitoneal chemotherapy is not a standard therapy. Anti-hormonal therapy with an aromatase inhibitor plays a minor role in therapy of both low grade serous ovarian cancer (LGSOC) and high grade serous ovarian cancer (HGSOC). A major achievement in ovarian cancer therapy has been the results of the SOLO-1 trial, in which olaparib as a first line maintenance monotherapy resulted in an overall $70 \%$ lower risk of disease progression in patients with advanced Breast Cancer Gene (BRCA)-mutated ovarian cancer.
\end{abstract}

Epithelial ovarian cancer is the second most common malignant disease of the female genital tract in Germany

This article is freely accessible online.

Correspondence to: Prof. Dr. med. Michael Friedrich, Klinik für Frauenheilkunde und Geburtshilfe, Helios Klinikum, Lutherplatz 40, 47805 Krefeld, Germany. Tel: +49 2151322201, Fax: +49 2151322220, e-mail: michael.friedrich@helios-gesundheit.de

Key Words: Ovarian cancer, treatment, surgery, chemotherapy, PARP inhibition, review. with approximately 7,400 new cases annually. Thus, one in 75 women will develop ovarian cancer during her lifetime. With 5,500 deaths annually, ovarian cancer is the leading gynecologic cause of death (1).

Over the past 15 years, the quality of treatment for ovarian cancer has been continuously improving. Median PFS has increased from 12.7 months in 2004 to 20.7 months in 2016 in FIGO stages III and IV. Treatment at an experienced center and an optimal tumor reduction during primary surgery is not least responsible for this (2).

\section{Morphologic Heterogeneity of Ovarian Cancer}

Epithelial ovarian cancer exhibits morphologic heterogeneity. Basically, five subtypes of epithelial ovarian cancer with different prognosis are differentiated: high grade serous (HGSOC, $80 \%$ ), low grade serous (LGSOC, 7\%), mucinous (3\%), clear cell (5\%), and endometrioid ovarian cancer (5\%) (Figure 1). The mutations and molecular alterations associated with epithelial ovarian cancer differ depending on the histologic subtype (3). For example, Konecny et al. (4) defined four molecular subtypes (immunoreactive-like, differentiated-like, proliferative-like, mesenchymal-like) in high-grade serous ovarian cancer, which are associated with different prognosis and show different therapeutic response to bevacizumab therapy. For instance, in a retrospective review of data from the AGO Ovarian Cancer 11/ICON7 trial, Kommoss et al. (5) demonstrated that the proliferative subtype of HGSOC benefited from bevacizumab therapy with a statistically significant improvement in median overall survival of 17.2 months, whereas no statistically significant benefit in overall survival was seen in any of the other molecular biology subtypes (Figure 2).

\section{Experience of Treatment Center}

Treatment center experience plays a crucial role in ovarian cancer therapy. In 2014 Bristow et al. (6) proved that patients 


\section{Morphological Heterogeneity \\ 5 Subtypes of epithelial Ovarian Cancer}

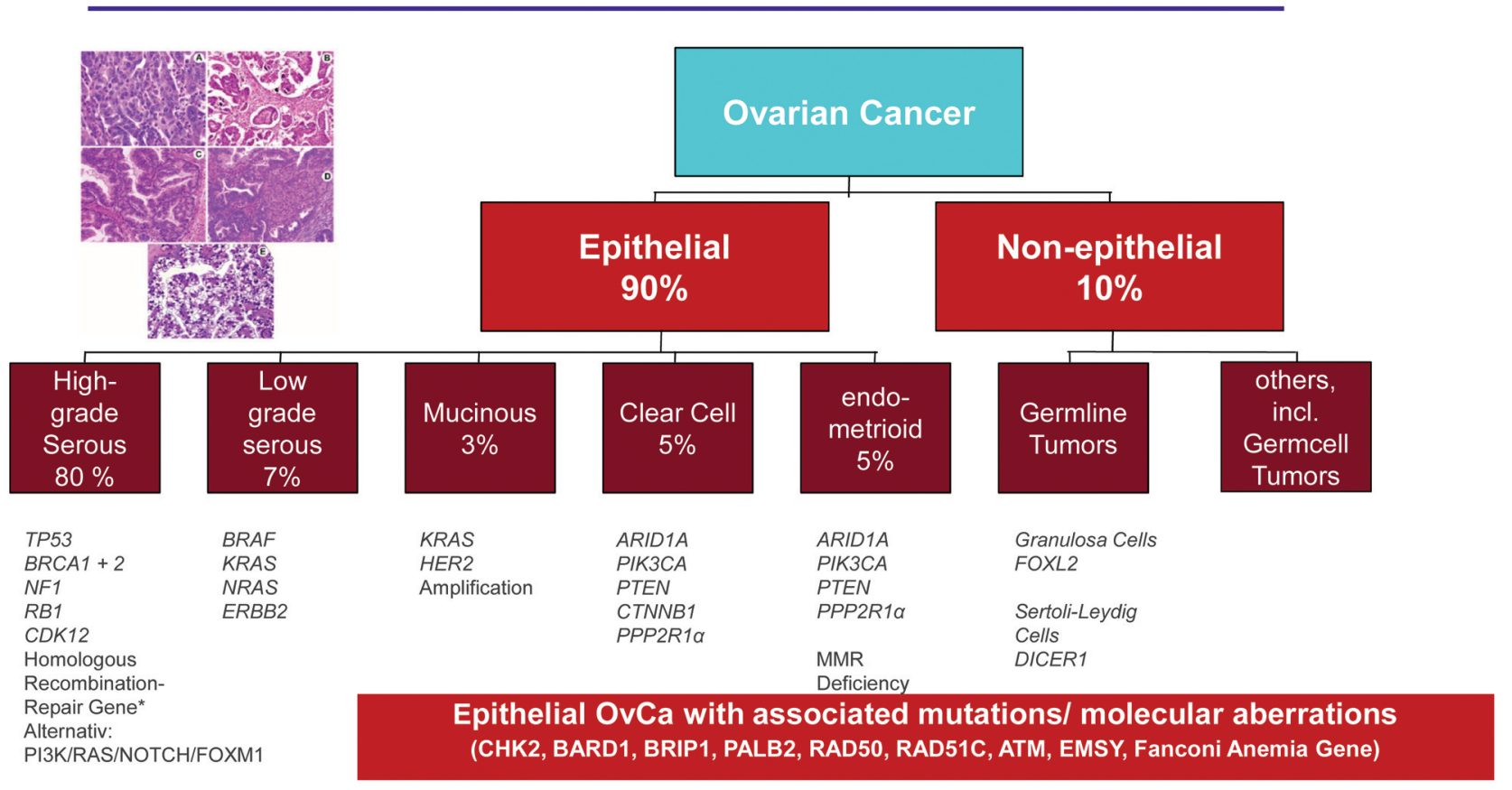

Modified from: Banerjee S and Kaye B | Clin Cancer Res 19(5): 961-968, 2013. PMID: 23307860. DOI: 10.1158/1078-0432.CCR-12-2243

Figure 1. Morphologic heterogeneity.

treated in a high-volume hospital (more than 20 cases per year) and by a high-volume surgeon (more than ten cases per year) have a significantly improved survival. This is due to the improved R0 resection rate. DuBois et al. (7), reviewing the AGO study data, showed that overall survival is worsened by a factor of 2.7 when a tumor remnant of $1-10 \mathrm{~mm}$ remains compared with R0 resection. Even if macroscopic tumor remission cannot be achieved, patients benefit from maximal tumor reduction. Thus, patients with a tumor remnant of 1$10 \mathrm{~mm}$ have a survival advantage of almost seven months compared to patients with a tumor remnant of more than 1 $\mathrm{cm}$. Compatible with this, Keyver-Paik et al. (8) showed an $\mathrm{R} 0$ resection rate in advanced ovarian cancer (FIGO stage IIB-IV) of more than $60 \%$ in an evaluation of more than 1000 ovarian cancers from 3 centers.

\section{Primary Debulking Surgery and Interval Debulking Surgery}

Surgery includes complete assessment of intra-abdominal tumor spread via median longitudinal laparotomy and careful exploration of the entire abdominal cavity, including inspection and palpation of the diaphragmatic domes, liver, omental bursa, paracolic gutters, small and large intestines, omentum majus and minus and retroperitoneal and para-aortic lymphatic ducts. Obtaining an aspiration cytology for cytologic examination is standard. The aim of surgery is to remove all visible tumor metastases. Limits of operability are given in case of extensive involvement of the small intestinal serosa, the small intestinal mesentery at the transition to the serosa, involvement of the mesenteric root or the truncus coeliacus and in case of diffuse infiltration of the stomach or pancreas.

If the postoperative tumor remnant is estimated to be larger than $1 \mathrm{~cm}$, the absolute radicality of the procedure should be discarded. Due to the lower chemosensitivity of low grade serous ovarian cancers, upfront debulking surgery has great importance especially in this situation. According to Harter et al. (9), $85.1 \%$ of patients received primary surgery with optimal cytoreduction followed by chemotherapy in Germany in 2016. Interval surgery after neoadjuvant chemotherapy was performed in $9.7 \%$, while only $5.2 \%$ of patients did not receive surgery. According to current data, systematic lymphonodectomy of clinical negative lymph nodes has no effect on overall survival in advanced ovarian cancer and should therefore no longer be 


\section{Moleculargenetic Heterogeneity \\ Significant Improvement of OAS with Bevacizumab in the proliferative Subtype of the EOC (AGO-Ovar 11/ICON7)}

\section{Benefit Bevacizumab + Standard Therapy vs. Standard Therapy}

\begin{tabular}{|c|c|c|c|c|}
\hline \multirow[b]{2}{*}{ Subtype } & \multirow{2}{*}{$\begin{array}{l}\text { Proliferative } \\
\quad(n=96)\end{array}$} & \multicolumn{3}{|c|}{ Non-proliferative } \\
\hline & & $\begin{array}{c}\text { Differentiated } \\
(n=73)\end{array}$ & $\begin{array}{c}\text { Mesenchymal } \\
(n=68)\end{array}$ & $\begin{array}{c}\text { Immunreactive } \\
(n=121)\end{array}$ \\
\hline \multicolumn{5}{|l|}{$\begin{array}{l}\text { Progression-free } \\
\text { Survival }\end{array}$} \\
\hline $\begin{array}{l}\Delta \mathrm{PFS}, \text { median } \\
\text { Improvement }\end{array}$ & 10.2 Months & 3.76 Months & 8.23 Months & 3.8 Months \\
\hline $\begin{array}{l}\mathrm{HR}(95 \% \mathrm{KI}) \\
p\end{array}$ & $\begin{array}{c}0.48(0.3-0.76) \\
p=0.002\end{array}$ & $\begin{array}{c}0.86(0.48-1.54) \\
p=0.615\end{array}$ & $\begin{array}{c}0.67(0.39-1.14) \\
p=0.138\end{array}$ & $\begin{array}{c}0,88(0.57-1.35) \\
p=0.546\end{array}$ \\
\hline \multicolumn{5}{|l|}{ Overall Survival } \\
\hline $\begin{array}{l}\Delta \mathrm{OS}, \text { median } \\
\text { Improvement }\end{array}$ & 17.2 Months & 23.03 Months & 11.77 Months & 1.5 Months \\
\hline $\begin{array}{l}\mathrm{HR}(95 \% \mathrm{KI}) \\
p\end{array}$ & $\begin{array}{c}0.54(0.32-0.91) \\
p=0.021\end{array}$ & $\begin{array}{c}0.69(0.34-1.38) \\
p=0.294\end{array}$ & $\begin{array}{c}0.75(0.40-1.41) \\
p=0.37\end{array}$ & $\begin{array}{c}1.01(0.6-1.7) \\
p=0.965\end{array}$ \\
\hline
\end{tabular}

Kommoss S et al. | J Clin Oncol 36(suppl): Abstract 5520, 2018.

Figure 2. Molecular-genetic heterogeneity and response to bevacizumab.

performed from FIGO stage IIB onwards. The results of the LION trial showed no significant difference in both, overall survival [65.5 months with lymphonodectomy (LNE) versus 67.2 months without LNE] and PFS. In contrast, lymphonodectomy was primarily associated with increased morbidity (infections, relaparotomies) and mortality.

Approximately $23 \%$ of ovarian cancers are diagnosed in women over the age of 75 . In addition, older patients are more likely to be classified in an advanced stage disease (FIGO III and IV) at initial diagnosis. Median overall survival in elderly patients is significantly worse at 30 vs. 64 months in a study by Trillsch et al. (10). This is due both to the significantly reduced rate of macroscopic tumor reduction during primary surgery and to the limited options for optimal platinum-based combination chemotherapy, which are significantly reduced to $40.4 \%$ versus $70.1 \%$. Thus, treatment decisions such as the indication for primary debulking surgery and optimal combination chemotherapy should be made individually based on the patient's general condition using, for example, the HADS score and not only based on age (11-14).
Interval debulking (IDS) in advanced ovarian cancer after three cycles of neoadjuvant chemotherapy with carboplatin/paclitaxel is controversial. Arguments in favor of IDS are a lower rate of postoperative complications, a lower surgical complexity with reduced procedure time, a lower blood loss and a shorter hospital stay. The value of neoadjuvant chemotherapy with three cycles of carboplatin and paclitaxel followed by interval debulking surgery has been evaluated in four prospective randomized phase IIItrials, whose validity is questioned because of deficiencies in study design and quality of surgical therapy (15-20). These deficiencies include: Bias with increased inclusion of patients with a poor prognosis; Significantly lower complete resection rates of only 16-19\% compared to $>50 \%$; Median duration of the operation is only 120 and 165 minutes, which is significantly lower than the expected operating time for a radical debulking operation. Nevertheless, IDS is a reasonable perspective especially for fragile patients or patients who cannot undergo radical surgery, for example due to pulmonary embolism at the time of diagnosis. 


\section{PARP-Inhibition (BEV +/- Olaparib) and PROC (PAOLA-1/ENGOT-OV25)}

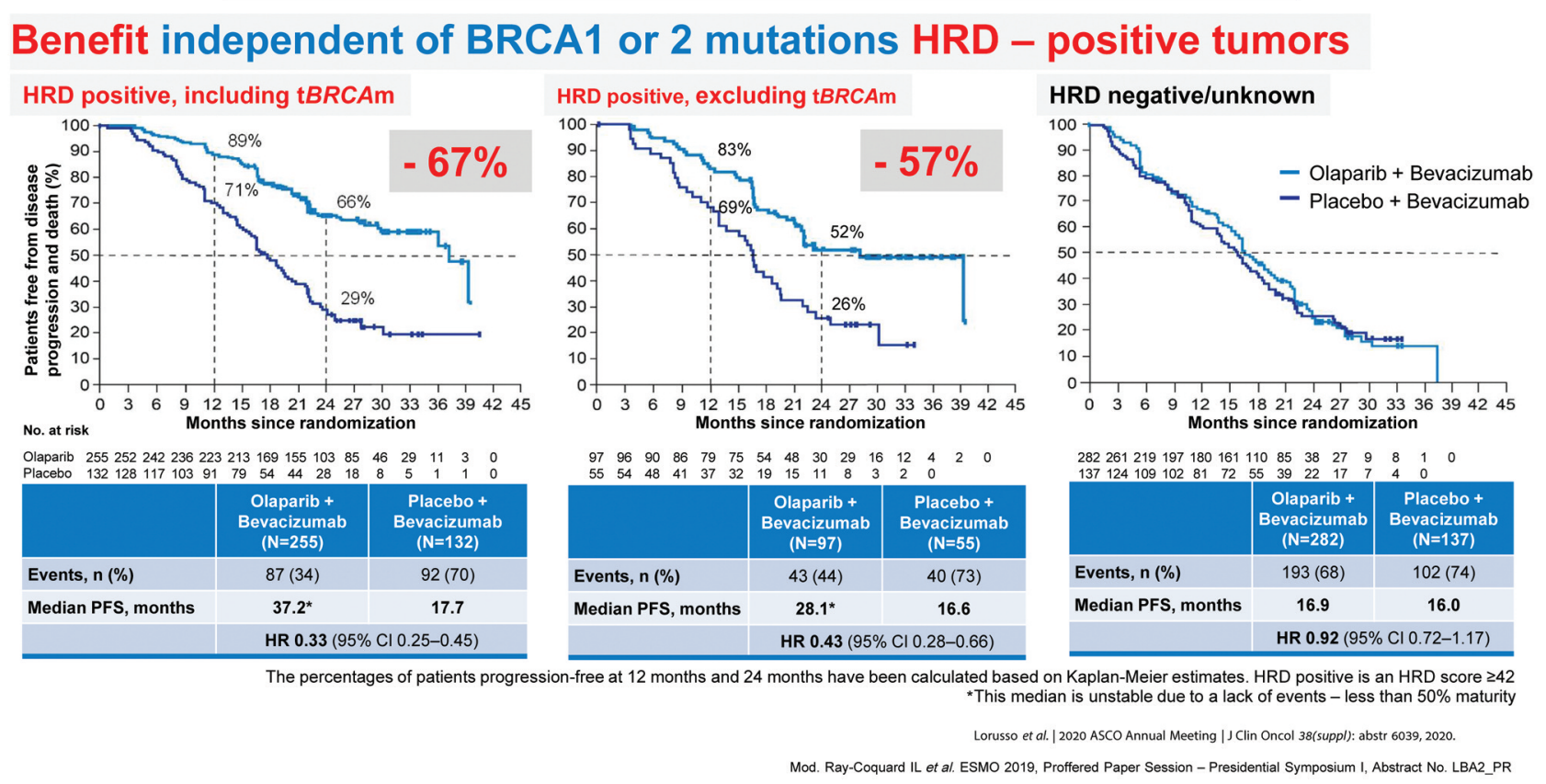

Figure 3. Results of the PAOLA-1/AGO-OVAR-20/ENGOT-OV25-Trial.

\section{Standard Chemotherapy}

Standard chemotherapy for advanced ovarian cancer consists of six cycles of carboplatin AUC5 and paclitaxel $175 \mathrm{mg} / \mathrm{m}^{2}$, in a three-week cycle. Studies investigating the efficacy of chemotherapy by adding additional chemotherapeutic agents in terms of triplets failed to improve prognosis. Even dosedense chemotherapy regimens (JGOG 3016, GOG 262, GOG 252, ICON 8, MITO-7), which for example lead to an improvement in prognosis in breast cancer, showed no significant improvement of overall survival (OAS) and (PFS) in ovarian cancer except in a Japanese study (JGOG 3016: med; OAS 100.5 months versus 62.2 months; HR=0.79; $p=0.039$ ) and in a subgroup of patients in the GOG 262 trial who did not receive bevacizumab therapy (PFS: 14.2 months versus 10.3 months; $\mathrm{HR}=0.62 ; p=0.03)(21-25)$.

\section{Intraperitoneal Chemotherapy and Hyperthermic Intraperitoneal Chemotherapy}

According to guidelines, intraperitoneal chemotherapy is not a standard therapy and should only be used in trials. Here, a distinction must be made between postoperative application as part of routine chemotherapy, e.g., intraperitoneal chemotherapy administration via a Tenkoff catheter, and intraoperative hyperthermic chemotherapy (HIPEC). A Cochrane meta-analysis (26) showed that postoperative intraperitoneal administration may be associated with $19 \%$ improved overall survival with significantly increased side effects and reduced dose intensity of systemic chemotherapy.

During HIPEC, after achieving R0 resection, the abdominal cavity is lavaged with chemotherapy for $1 \mathrm{~h}$ at a temperature of approximately $40^{\circ} \mathrm{C}$ during surgery. The possible advantage of this therapy could be due to additive cytotoxic effects from chemotherapy, for example with cisplatin, and hyperthermia at the cellular and tissue level. Increased cytotoxicity with intensified "DNA crosslinking" and improved peritoneal tumor penetration of the chemotherapeutic agent is also conceivable (27-29). In the first line situation, only one prospective randomized phase III trial in advanced ovarian cancer, which investigated the value of HIPEC with $100 \mathrm{mg}$ cisplatin in the setting of IDS, has found a significant improvement in overall survival with 48 months versus 34 months (30). Many questions such as the type of intraperitoneal chemotherapy to be used (mono- versus combination-chemotherapy), the duration of intraperitoneal irrigation and the possible complications and side effects remain open, so that this form of chemotherapy should only be evaluated in trials. 


\section{Maintenance Therapy}

Anti-hormonal therapy with an aromatase inhibitor plays a minor role in therapy. Nevertheless, studies with small case numbers in both LGSOC and HGSOC have shown a survival benefit in advanced ovarian cancer (31).

A significant development for the concept of maintenance therapy in advanced primary ovarian cancer has been achieved with two phase III trials in Europe and the USA with bevacizumab. In the GOG 218 trial, maintenance therapy with bevacizumab for 16 cycles after completion of chemotherapy showed a 3.8-month significant increase in PFS (14.1 months versus 10.3 months; $\mathrm{HR}=0.72$ ) compared with the standard therapy at that time (carboplatin/paclitaxel). The AGO-OVAR 11 (ICON 7) trial showed comparable results with a significantly prolonged PFS of 2.4 months (16.9 months versus 19.3 months; $\mathrm{HR}=0.81 ; p=0.004)$. Patients at high risk of recurrence (FIGO III with tumor residue greater than $1 \mathrm{~cm}$, FIGO IV) benefited in this study with an increase in overall survival of 7.8 months (36.6 versus 28.8 months; $\mathrm{HR}=0.64$; $p=0.002$ ). In contrast, the GOG 218 study showed an increase in recurrence rate after completion of bevacizumab maintenance therapy. Therefore, an extension of bevacizumab maintenance therapy over a period of more than one year is being evaluated. In the AGO-OVAR17 trial, a doubling of bevacizumab therapy time from 22 to 44 cycles is being investigated $(32,33)$.

$B R C A$ mutations play an important role in ovarian cancer. It is currently estimated that approximately $35 \%$ of $B R C A$ mutation carriers have no family history of $B R C A$ mutation. More than one-third of platinum-sensitive recurrences have BRCA mutations. Approximately $6 \%$ of ovarian cancers have a somatic BRCA mutation without a germline mutation. Somatic and germline mutations in the BRCAl and 2 genes lead to loss of $B R C A$ function. This results in impairment of homologous recombination repair of DNA and thus an increase in platinum sensitivity. The DNA repair enzyme PARP plays a crucial role in the occurrence of DNA doublestrand breaks. In cancer cells lacking other components of DNA repair due to tumor genetic characteristics (BRCA1 and 2 or HRD), inhibition of the PARP enzyme prevents adequate repair of the DNA damage, which subsequently leads to increased genomic instability of the tumor cells and even to their cell death. Thus, PARP inhibition plays a therapeutic role in the treatment of ovarian cancer (34).

A major achievement in ovarian cancer treatment is the results of the SOLO-1 study, which evaluated olaparib first line maintenance monotherapy for 24 months in patients with advanced BRCA mutated ovarian cancer. In that study, olaparib therapy showed an overall $70 \%$ lower risk of disease progression $(\mathrm{HR}=0.30 \quad(95 \% \mathrm{CI}=0.23-0.41)$, $p<0.001)$. With a median PFS of 56 months with 25 months of olaparib therapy, the beneficial effect persists beyond olaparib therapy, so there is also reasonable hope for improvement in OAS $(35,36)$.

In three additional first line phase III maintenance therapy trials (37) with the PARP inhibitor niraparib after response to platinum-containing chemotherapy, there was a significant improvement in PFS of 13.8 months versus 8.2 months in the placebo group $(\mathrm{HR}=0.62 ; 95 \% \mathrm{CI}=0.50$ 0.76), regardless of $B R C A$ mutation status. In patients whose tumor was HR-deficient, therapy with niraparib resulted in a significant improvement in PFS and a reduction in the risk of progression of $57 \%$. Even in HRcompetent tumors, niraparib therapy resulted in a $32 \%$ reduced risk of progression compared to placebo therapy [HR=0.68; (95\%CI=0.49-0.94); $p=0.02]$. It should be mentioned that in this study patients in the standard arm did not receive bevacizumab therapy and patients with R0 resection during primary surgery for FIGO III stage have been excluded.

For a long time, it was unclear when bevacizumab therapy or PARP inhibition should be used in the first line situation. In the PAOLA-1/AGO-OVAR-20 trial $(38,39)$, the efficacy of combination maintenance therapy with olaparib and bevacizumab was investigated for the first time in patients with advanced ovarian cancer regardless of $B R C A$ mutation status. This showed a benefit in PFS in HRD-positive patients independently of BRCA mutation status (Figure 3).

Furthermore, a significant improvement in PFS was shown even after first progression regardless of $B R C A$ mutation status with HRD positivity in the context of combination maintenance therapy of olaparib and bevacizumab. Although overall survival data are currently pending, an improvement in OAS is likely.

PARP inhibitors are nowadays the new standard in the first line therapy of advanced ovarian cancer. BRCA and HRD testing are essential for choosing the right therapy. Even in BRCAwt/HR-deficient tumors, patients benefit from PARP inhibition. Thus, HRD testing should be performed in BRCA negative patients to provide access to effective PARP inhibition therapy. In patients without evidence of HRD, consideration must be given to whether therapy with niraparib or bevacizumab is preferred. This comparison is still pending from the studies to date.

\section{Conflicts of Interest}

All Authors declare that they have no conflicts of interest in relation to this study.

\section{Authors' Contributions}

MF and DF wrote the paper in the German language, CR performed the translation in English and CK checked the English spelling as a native speaker. All Authors contributed to editorial changes in the manuscript. All Authors read and approved the final manuscript. 


\section{References}

1 Robert Koch-Institut und Gesellschaft der epidemiologischen Krebsregister in Deutschland e. V., Krebs in Deutschland 2015/2016. Häufigkeiten und Trends. 12. Auflage. Stand 2019. Available at: https://edoc.rki.de/handle/176904/6012\#: :text= In $\% 202016 \% 20$ sind $\% 20$ gesch $\%$ C3\%A4tzt $\% 20$ ca,auf\%20rund $\% 20$ $510.000 \% 20$ Erkrankungsf\%C3\%A4lle\%20auszugehen [Last accessed on May 21, 2021]

2 Du Bois A, Harter P, Pfisterer J and Hilpert F: Therapiequalität des fortgeschrittenen Ovarialkarzinoms in Deutschland. Frauenarzt 61(3): 182-188, 2020.

3 Banerjee S and Kaye SB: New strategies in the treatment of ovarian cancer: current clinical perspectives and future potential. Clin Cancer Res 19(5): 961-968, 2013. PMID: 23307860. DOI: 10.1158/1078-0432.CCR-12-2243

4 Konecny GE, Wang C, Hamidi H, Winterhoff B, Kalli KR, Dering J, Ginther C, Chen HW, Dowdy S, Cliby W, Gostout B, Podratz KC, Keeney G, Wang HJ, Hartmann LC, Slamon DJ and Goode EL: Prognostic and therapeutic relevance of molecular subtypes in high-grade serous ovarian cancer. J Natl Cancer Inst 106(10): dju249, 2014. PMID: 25269487. DOI: 10.1093/jnci/dju249

5 Kommoss S, Winterhoff B, Oberg AL, Konecny GE, Wang C, Riska SM, Fan JB, Maurer MJ, April C, Shridhar V, Kommoss F, du Bois A, Hilpert F, Mahner S, Baumann K, Schroeder W, Burges A, Canzler U, Chien J, Embleton AC, Parmar M, Kaplan R, Perren T, Hartmann LC, Goode EL, Dowdy SC and Pfisterer J: Bevacizumab may differentially improve ovarian cancer outcome in patients with proliferative and mesenchymal molecular subtypes. Clin Cancer Res 23(14): 3794-3801, 2017. PMID: 28159814. DOI: 10.1158/10780432.CCR-16-2196

6 Bristow RE, Chang J, Ziogas A, Randall LM and Anton-Culver $\mathrm{H}$ : High-volume ovarian cancer care: survival impact and disparities in access for advanced-stage disease. Gynecol Oncol 132(2): 403-410, 2014. PMID: 24361578. DOI: 10.1016/ j.ygyno.2013.12.017

7 du Bois A, Reuss A, Pujade-Lauraine E, Harter P, Ray-Coquard I and Pfisterer J: Role of surgical outcome as prognostic factor in advanced epithelial ovarian cancer: a combined exploratory analysis of 3 prospectively randomized phase 3 multicenter trials: by the Arbeitsgemeinschaft Gynaekologische Onkologie Studiengruppe Ovarialkarzinom (AGO-OVAR) and the Groupe d'Investigateurs Nationaux Pour les Etudes des Cancers de l'Ovaire (GINECO). Cancer 115(6): 1234-1244, 2009. PMID: 19189349. DOI: $10.1002 / \mathrm{cncr} .24149$

8 Keyver-Paik MD, Abramian A, Domröse C, Döser A, Höller T, Friedrich M, Meier W, Menn K and Kuhn W: Integrated care in ovarian cancer "IgV Ovar": results of a German pilot for higher quality in treatment of ovarian cancer. J Cancer Res Clin Oncol 142(2): 481-487, 2016. PMID: 26498774. DOI: 10.1007/s00432015-2055-6

9 Harter P, Sehouli J, Lorusso D, Reuss A, Vergote I, Marth C, Kim JW, Raspagliesi F, Lampe B, Aletti G, Meier W, Cibula D, Mustea A, Mahner S, Runnebaum IB, Schmalfeldt B, Burges A, Kimmig R, Scambia G, Greggi S, Hilpert F, Hasenburg A, Hillemanns P, Giorda G, von Leffern I, Schade-Brittinger C, Wagner U and du Bois A: A randomized trial of lymphadenectomy in patients with advanced ovarian neoplasms. N Engl J Med 380(9): 822-832, 2019. PMID: 30811909. DOI: 10.1056/NEJMoa1808424
10 Trillsch F, Woelber L, Eulenburg C, Braicu I, Lambrechts S, Chekerov R, van Nieuwenhuysen E, Speiser P, Zeimet A, Castillo-Tong DC, Concin N, Zeillinger R, Vergote I, Mahner S and Sehouli J: Treatment reality in elderly patients with advanced ovarian cancer: a prospective analysis of the OVCAD consortium. J Ovarian Res 6(1): 42, 2013. PMID: 23809664. DOI: $10.1186 / 1757-2215-6-42$

11 Bardram L, Funch-Jensen P, Jensen P, Crawford ME and Kehlet $\mathrm{H}$ : Recovery after laparoscopic colonic surgery with epidural analgesia, and early oral nutrition and mobilisation. Lancet 345(8952): 763-764, 1995. PMID: 7891489. DOI: 10.1016/ s0140-6736(95)90643-6

12 Modesitt SC, Sarosiek BM, Trowbridge ER, Redick DL, Shah PM, Thiele RH, Tiouririne M and Hedrick TL: Enhanced recovery implementation in major gynecologic surgeries: Effect of care standardization. Obstet Gynecol 128(3): 457-466, 2016. PMID: 27500337. DOI: 10.1097/AOG.0000000000001555

13 Nelson G, Altman AD, Nick A, Meyer LA, Ramirez PT, Achtari C, Antrobus J, Huang J, Scott M, Wijk L, Acheson N, Ljungqvist $\mathrm{O}$ and Dowdy SC: Guidelines for postoperative care in gynecologic/oncology surgery: Enhanced Recovery After Surgery (ERAS $\left.{ }^{\circ}\right)$ Society recommendations-Part II. Gynecol Oncol 140(2): 323-332, 2016. PMID: 26757238. DOI: 10.1016/j.ygyno.2015.12.019

14 Kalogera E, Bakkum-Gamez JN, Jankowski CJ, Trabuco E, Lovely JK, Dhanorker S, Grubbs PL, Weaver AL, Haas LR, Borah BJ, Bursiek AA, Walsh MT, Cliby WA and Dowdy SC: Enhanced recovery in gynecologic surgery. Obstet Gynecol 122(2 Pt 1): 319-328, 2013. PMID: 23969801. DOI: 10.1097/ AOG.0b013e31829aa780

15 Kehoe S, Hook J, Nankivell M, Jayson GC, Kitchener H, Lopes T, Luesley D, Perren T, Bannoo S, Mascarenhas M, Dobbs S, Essapen S, Twigg J, Herod J, McCluggage G, Parmar M and Swart AM: Primary chemotherapy versus primary surgery for newly diagnosed advanced ovarian cancer (CHORUS): an open-label, randomised, controlled, non-inferiority trial. Lancet 386(9990): 249-257, 2015. PMID: 26002111. DOI: 10.1016/S0140-6736(14)62223-6

16 Vergote I, Tropé CG, Amant F, Kristensen GB, Ehlen T, Johnson $\mathrm{N}$, Verheijen RH, van der Burg ME, Lacave AJ, Panici PB, Kenter GG, Casado A, Mendiola C, Coens C, Verleye L, Stuart GC, Pecorelli S, Reed NS, European Organization for Research and Treatment of Cancer-Gynaecological Cancer Group and NCIC Clinical Trials Group: Neoadjuvant chemotherapy or primary surgery in stage IIIC or IV ovarian cancer. N Engl J Med 363(10): 943-953, 2010. PMID: 20818904. DOI: 10.1056/NEJMoa0908806

17 Fagotti A, Vizzielli G, Ferrandina G, Fanfani F, Gallotta V, Chiantera V, Costantini B, Margariti P, Gueli alletti S, Cosentino F, Tortorella L and Scambia G: Survival analyses from a randomized trial of primary debulking surgery versus neoadjuvant chemotherapy for advanced epithelial ovarian cancer with high tumor load (SCORPION trial). Journal of Clinical Oncology 36(15_suppl): 5516-5516, 2019. DOI: 10.1200/jco.2018.36.15_suppl.5516

18 Onda T, Satoh T, Ogawa G, Saito T, Kasamatsu T, Nakanishi T, Mizutani T, Takehara K, Okamoto A, Ushijima K, Kobayashi H, Kawana K, Yokota H, Takano M, Kanao H, Watanabe Y, Yamamoto K, Yaegashi N, Kamura T, Yoshikawa H and Japan Clinical Oncology Group: Comparison of survival between primary debulking surgery and neoadjuvant chemotherapy for 
stage III/IV ovarian, tubal and peritoneal cancers in phase III randomised trial. Eur J Cancer 130: 114-125, 2020. PMID: 32179446. DOI: 10.1016/j.ejca.2020.02.020

19 Mahner S, Du bois A, Pfisterer J, Hilpert F, Sehouli J, Lamparter C, Kerkmann $\mathrm{M}$ and Harter P: Behandlungsqualität des Ovarialkarzinoms in Deutschland: Aktuelle Ergebnisse des Qualitätssicherungsprogramms QS OVAR. Abstracts zum Kongress 2019 der Bayerischen Gesellschaft für Geburtshilfe und Frauenheilkunde (BGGF) und der Österreichischen Gesellschaft für Gynäkologie und Geburtshilfe (OEGGG), 2019. DOI: $10.1055 / \mathrm{S}-0039-1693901$

20 Kehoe S, Hook J, Nankivell M, Jayson GC, Kitchener H, Lopes T, Luesley D, Perren T, Bannoo S, Mascarenhas M, Dobbs S, Essapen S, Twigg J, Herod J, McCluggage G, Parmar M and Swart AM: Primary chemotherapy versus primary surgery for newly diagnosed advanced ovarian cancer (CHORUS): an openlabel, randomised, controlled, non-inferiority trial. Lancet 386(9990): 249-257, 2015. PMID: 26002111. DOI: 10.1016/ S0140-6736(14)62223-6

21 Pignata S, Scambia G, Katsaros D, Gallo C, Pujade-Lauraine E, De Placido S, Bologna A, Weber B, Raspagliesi F, Panici PB, Cormio G, Sorio R, Cavazzini MG, Ferrandina G, Breda E, Murgia V, Sacco C, Cinieri S, Salutari V, Ricci C, Pisano C, Greggi S, Lauria R, Lorusso D, Marchetti C, Selvaggi L, Signoriello S, Piccirillo MC, Di Maio M, Perrone F, Multicentre Italian Trials in Ovarian cancer (MITO-7), Groupe d'Investigateurs Nationaux pour l'Etude des Cancers Ovariens et du sein (GINECO), Mario Negri Gynecologic Oncology (MaNGO), European Network of Gynaecological Oncological Trial Groups (ENGOT-OV-10) and Gynecologic Cancer InterGroup (GCIG) Investigators: Carboplatin plus paclitaxel once a week versus every 3 weeks in patients with advanced ovarian cancer (MITO-7): a randomised, multicentre, open-label, phase 3 trial. Lancet Oncol 15(4): 396-405, 2014 PMID: 24582486. DOI: 10.1016/S1470-2045(14)70049-X

22 Katsumata N, Yasuda M, Isonishi S, Takahashi F, Michimae H, Kimura E, Aoki D, Jobo T, Kodama S, Terauchi F, Sugiyama T, Ochiai K and Japanese Gynecologic Oncology Group: Longterm results of dose-dense paclitaxel and carboplatin versus conventional paclitaxel and carboplatin for treatment of advanced epithelial ovarian, fallopian tube, or primary peritoneal cancer (JGOG 3016): a randomised, controlled, open-label trial. Lancet Oncol 14(10): 1020-1026, 2013. PMID: 23948349. DOI: 10.1016/S1470-2045(13)70363-2

23 Chan JK, Brady MF, Penson RT, Huang H, Birrer MJ, Walker JL, DiSilvestro PA, Rubin SC, Martin LP, Davidson SA, Huh WK, O'Malley DM, Boente MP, Michael H and Monk BJ: Weekly vs. every-3-week paclitaxel and carboplatin for ovarian cancer. N Engl J Med 374(8): 738-748, 2016. PMID: 26933849. DOI: $10.1056 /$ NEJMoa1505067

24 Clamp AR, James EC, McNeish IA, Dean A, Kim JW, O’Donnell DM, Hook J, Coyle C, Blagden S, Brenton JD, Naik R, Perren T, Sundar S, Cook AD, Gopalakrishnan GS, Gabra H, Lord R, Dark G, Earl HM, Hall M, Banerjee S, Glasspool RM, Jones R, Williams S, Swart AM, Stenning S, Parmar M, Kaplan $\mathrm{R}$ and Ledermann JA: Weekly dose-dense chemotherapy in firstline epithelial ovarian, fallopian tube, or primary peritoneal carcinoma treatment (ICON8): primary progression free survival analysis results from a GCIG phase 3 randomised controlled trial. Lancet 394(10214): 2084-2095, 2019. PMID: 31791688. DOI: $10.1016 / \mathrm{S} 0140-6736(19) 32259-7$
25 Walker JL: Intraperitoneal chemotherapy for ovarian cancer. Gynecol Oncol 142(1): 1-2, 2016. PMID: 27328898. DOI: 10.1016/j.ygyno.2016.06.011

26 Jaaback K, Johnson $\mathrm{N}$ and Lawrie TA: Intraperitoneal chemotherapy for the initial management of primary epithelial ovarian cancer. Cochrane Database Syst Rev (1): CD005340, 2016. PMID: 26755441. DOI: 10.1002/14651858.CD005340.pub4

27 Blommaert FA, Michael C, Terheggen PM, Muggia FM, Kortes V, Schornagel JH, Hart AA and den Engelse L: Drug-induced DNA modification in buccal cells of cancer patients receiving carboplatin and cisplatin combination chemotherapy, as determined by an immunocytochemical method: interindividual variation and correlation with disease response. Cancer Res 53(23): 5669-5675, 1993. PMID: 8242622.

28 Los G, van Vugt MJ and Pinedo HM: Response of peritoneal solid tumours after intraperitoneal chemohyperthermia treatment with cisplatin or carboplatin. Br J Cancer 69(2): 235-241, 1994. PMID: 8297720. DOI: 10.1038/bjc.1994.45

29 van de Vaart PJ, van der Vange N, Zoetmulder FA, van Goethem AR, van Tellingen O, ten Bokkel Huinink WW, Beijnen JH, Bartelink H and Begg AC: Intraperitoneal cisplatin with regional hyperthermia in advanced ovarian cancer: pharmacokinetics and cisplatin-DNA adduct formation in patients and ovarian cancer cell lines. Eur J Cancer 34(1): 148-154, 1998. PMID: 9624250. DOI: $10.1016 / \mathrm{s} 0959-8049(97) 00370-5$

30 van Driel WJ, Koole SN, Sikorska K, Schagen van Leeuwen JH, Schreuder HWR, Hermans RHM, de Hingh IHJT, van der Velden J, Arts HJ, Massuger LFAG, Aalbers AGJ, Verwaal VJ, Kieffer JM, Van de Vijver KK, van Tinteren H, Aaronson NK and Sonke GS: Hyperthermic intraperitoneal chemotherapy in ovarian cancer. N Engl J Med 378(3): 230-240, 2018. PMID: 29342393. DOI: 10.1056/NEJMoa1708618

31 Heinzelmann-Schwarz V, Knipprath Mészaros A, Stadlmann S, Jacob F, Schoetzau A, Russell K, Friedlander M, Singer G and Vetter M: Letrozole may be a valuable maintenance treatment in high-grade serous ovarian cancer patients. Gynecol Oncol 148(1): 79-85, 2018. PMID: 29157627. DOI: 10.1016/j.ygyno.2017.10.036

32 Burger RA, Brady MF, Bookman MA, Fleming GF, Monk BJ, Huang H, Mannel RS, Homesley HD, Fowler J, Greer BE, Boente M, Birrer MJ, Liang SX and Gynecologic Oncology Group: Incorporation of bevacizumab in the primary treatment of ovarian cancer. N Engl J Med 365(26): 2473-2483, 2011. PMID: 22204724. DOI: 10.1056/NEJMoa1104390

33 Perren TJ, Swart AM, Pfisterer J, Ledermann JA, PujadeLauraine E, Kristensen G, Carey MS, Beale P, Cervantes A, Kurzeder C, du Bois A, Sehouli J, Kimmig R, Stähle A, Collinson F, Essapen S, Gourley C, Lortholary A, Selle F, Mirza MR, Leminen A, Plante M, Stark D, Qian W, Parmar MK, Oza AM and ICON7 Investigators: A phase 3 trial of bevacizumab in ovarian cancer. N Engl J Med 365(26): 2484-2496, 2011. PMID: 22204725. DOI: 10.1056/NEJMoa1103799

34 Farmer H, McCabe N, Lord CJ, Tutt AN, Johnson DA, Richardson TB, Santarosa M, Dillon KJ, Hickson I, Knights C, Martin NM, Jackson SP, Smith GC and Ashworth A: Targeting the DNA repair defect in BRCA mutant cells as a therapeutic strategy. Nature 434(7035): 917-921, 2005. PMID: 15829967. DOI: $10.1038 /$ nature03445

35 Moore K, Colombo N, Scambia G, Kim BG, Oaknin A, Friedlander M, Lisyanskaya A, Floquet A, Leary A, Sonke GS, Gourley C, Banerjee S, Oza A, González-Martín A, Aghajanian 
C, Bradley W, Mathews C, Liu J, Lowe ES, Bloomfield R and DiSilvestro P: Maintenance olaparib in patients with newly diagnosed advanced ovarian cancer. N Engl J Med 379(26): 2495-2505, 2018. PMID: 30345884. DOI: 10.1056/NEJ Moa1810858

36 DiSilvestro P, Colombo N, Scambia G, Kim BG, Oaknin A, Friedlander M, Lisyanskaya A, Floquet A, Leary A, Sonke GS, Gourley C, Banerjee S, Oza A, González-Martín A, Aghajanian CA, Bradley WH, Mathews CA, Liu J, Lowe ES, Bloomfield R and Moore KN: Efficacy of maintenance olaparib for patients with newly diagnosed advanced ovarian cancer with a BRCA mutation: Subgroup analysis findings from the SOLO1 trial. J Clin Oncol 38(30): 3528-3537, 2020. PMID: 32749942. DOI: 10.1200/JCO.20.00799

37 González-Martín A, Pothuri B, Vergote I, DePont Christensen R, Graybill W, Mirza MR, McCormick C, Lorusso D, Hoskins P, Freyer G, Baumann K, Jardon K, Redondo A, Moore RG, Vulsteke C, O'Cearbhaill RE, Lund B, Backes F, BarretinaGinesta P, Haggerty AF, Rubio-Pérez MJ, Shahin MS, Mangili G, Bradley WH, Bruchim I, Sun K, Malinowska IA, Li Y, Gupta D, Monk BJ and PRIMA/ENGOT-OV26/GOG-3012 Investigators: Niraparib in Patients with Newly Diagnosed Advanced Ovarian Cancer. N Engl J Med 381(25): 2391-2402, 2019. PMID: 31562799. DOI: 10.1056/NEJMoa1910962
38 Ray-Coquard I, Pautier P, Pignata S, Pérol D, González-Martín A, Berger R, Fujiwara K, Vergote I, Colombo N, Mäenpää J, Selle F, Sehouli J, Lorusso D, Guerra Alía EM, Reinthaller A, Nagao S, Lefeuvre-Plesse C, Canzler U, Scambia G, Lortholary A, Marmé F, Combe P, de Gregorio N, Rodrigues M, Buderath P, Dubot C, Burges A, You B, Pujade-Lauraine E, Harter P and PAOLA-1 Investigators: Olaparib plus bevacizumab as first-line maintenance in ovarian cancer. N Engl J Med 381(25): 24162428, 2019. PMID: 31851799. DOI: 10.1056/NEJMoa1911361

39 Lorusso D, Lotz J, Harter P, Cropet C, Rubio pérez M, Schauer C, Matsumoto T, Vergote I, Colombo N, Noettrup T, Bourgeois H, Schnelzer A, Pignata S, Garcia Y, Provansal M, Hanker L, Berton D, Bauerschlag D, Joly $\mathrm{F}$ and Ray-coquard I: Maintenance olaparib plus bevacizumab (bev) after platinumbased chemotherapy plus bev in patients (pts) with newly diagnosed advanced high-grade ovarian cancer (HGOC): Efficacy by BRCA1 or BRCA2 mutation in the phase III PAOLA-1 trial. Journal of Clinical Oncology 38(15_suppl): 6039-6039, 2020. DOI: 10.1200/JCO.2020.38.15_suppl.6039

Received April 19, 2021

Revised May 17, 2021

Accepted May 21, 2021 